\title{
Determining the Optimum Conditions for Extracting Carotenoids from Syrian Apricot Fruits
}

\author{
Wahbi Kalook $^{1^{*}}$, Adib Faleh ${ }^{1}$, Amir Al-Haj Sakur ${ }^{2}$ and Wassim Abdelwahed ${ }^{2}$ \\ ${ }^{1}$ Department of Food Science, Faculty of Agriculture, Aleppo University, Syria. \\ ${ }^{2}$ Faculty of Pharmacy, Aleppo University, Syria.
}

Authors' contributions

This work was carried out in collaboration among all authors. All authors read and approved the final manuscript.

Article Information

DOI: 10.9734/ARRB/2021/v36i930419

Editor(s):

(1) Dr. Bechan Sharma, University of Allahabad, India.

Reviewers:

(1) B. N. Hazarika, Central Agricultural University, India. (2) Jayoti Majumder, Bidhan Chabdra Krishi Viswavidyalaya, India. Complete Peer review History: https://www.sdiarticle4.com/review-history/72933

Original Research Article

Received 25 June 2021

Accepted 01 September 2021

Published 01 September 2021

\begin{abstract}
The aim of this research is to extract carotenoids from apricot fruits using a food solvent (ethanol) and a non-food solvent (propanol). In addition, it aims to study the effect of different extraction conditions, i.e., the extraction temperature $(20-40-60)^{\circ} \mathrm{C}$ and the extraction times (4-8-12) hours, on the carotenoids yield in order to improve and develop extraction methods. The extracted carotenoids were determined using high-performance liquid chromatography (HPLC), and the studied carotenoids are $\alpha$-carotene and $\beta$-carotene. It was found that $\beta$-carotene constitutes about $80 \%$ of the total carotenoids in apricots. The results indicated that the extraction yield using ethanol was low compared to the extraction yield using propanol. Propanol is the most suitable solvent for carotenoids extraction in comparison with ethanol. The temperature also had a significant effect on the extraction yield; at $20^{\circ} \mathrm{C}$ the extraction yield was very low, and $60^{\circ} \mathrm{C}$ was the optimum temperature for the extraction of carotene. The extraction yield significantly increased with time in the first hours of extraction, and there was no significant effect from increasing the extraction time for a period of 6-8 hours. Moreover, the pretreatment of fruits by freezing accelerated the extraction process and increased the extraction yield. The optimum conditions for extracting carotenoids were determined in the conditions of food extraction; the optimum conditions for extracting carotenoids are: extraction at $60^{\circ} \mathrm{C}$ for three hours with pretreatment by freezing as the extraction rate reached up to $6.36 \mathrm{mg} / 100 \mathrm{~g}$ using ethanol as a food solvent.
\end{abstract}


Keywords: Apricot; extract; carotenoids; ethanol; propanol.

\section{INTRODUCTION AND LITERATURE REVIEW}

The global production of fruits and vegetables has increased in the past few decades as a result of the use of modern technologies in the fields of agriculture. However, the waste of fruits and vegetables in developing countries during post-harvest operations has been estimated at $25 \%$ and may reach more than $50 \%$ for some types due to self-decomposition, germination, microbiological and parasitic infections, etc [1]

Fruits and vegetables provide the human body with important nutrients such as minerals, vitamins and fiber. Humans obtain over $90 \%$ of their vitamin $\mathrm{C}$ needs from fruits and vegetables, $50 \%$ of their vitamin A needs, $20 \%$ of their needs of thiamine and niacin, and $25 \%$ of their needs of iron and magnesium [2].

Stone fruits belong to the family Rosaceae, subfamily Prunoidae, genus Prunus, which include apricot, peach, plum and cherry. All the fruits of the genus Prunus are Drupes, and they are called stone fruit due to having a hard shell surrounding the kernel. This shell is the inner layer of the wall of the mature ovary (endocarp), and the edible part in these fruits is the outer layer (exocarp), and the middle layer (mesocarp) of the ovarian wall (pericarp). Fig. (1) shows the three layers of stone fruits.

The global production of fruits and vegetables is estimated at approx. 434.7 million tons/year [3]. The cultivated area of apricot trees is estimated at approx. 13801 hectares, and the annual production is estimated at approx. 72,000 tons per year [4].

The nutritional value of apricot fruits comes from their chemical composition: 10\% sugars, $1.3 \%$ organic acids, $0.7 \%$ ash, $0.8 \%$ fiber, $0.07 \%$ tannins, and $0.5 \%$ pectin. Vitamin $C$ constitutes about $10 \mathrm{mg} / 100 \mathrm{~g}$. Apricots are very rich in carotenoids and have the ability to inhibit free oxygen radicals [5].

Apricot is one of the Climacteric fruits, which are characterized by a short preservation period of not more than two weeks due to the high respiration rate and the fast-ripening processes [6]. In order to increase the shelf life of these fruits, many different preservation techniques have been developed including canning, freezing, drying, and packaging in a modified medium [7], as well as processing in various forms. The nutritional value of the processed fruits decreases according to processing methods, duration, temperature and storage conditions. In addition, some preservation processes can lead to the depletion of biologically active compounds responsible for antioxidant activity, and heat treatment of fruits leads to a decrease in their quality as a result of sharp changes in the shape, histological composition, texture and chemical composition of these products [8].

The biologically active compounds responsible for the antioxidant activity, known as antioxidants, are compounds that are able to prevent or hinder the oxidation of other compounds by giving electrons to free radicals, which in turn turn into weak, ineffective and nontoxic free radicals forming a barrier that inhibits or delays oxidation in cellular systems by stopping the oxidation chain reactions that produce free radicals that are known for their activity and efficacy in tissues. Vitamins A, C, and $\mathrm{E}$, carotenoids, terpene, polyphenols, flavonoids, and phenolic acids are among the most important natural antioxidants, and most of these materials have been observed to naturally exist in fruits and vegetables [9].

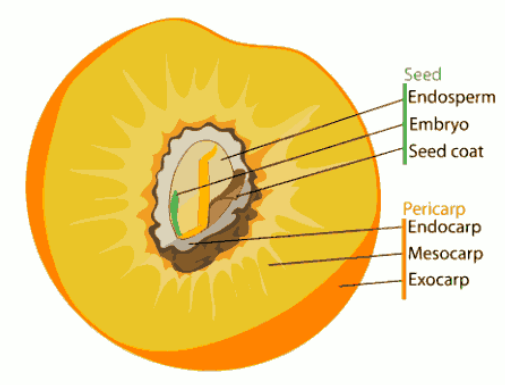

Fig. 1. The three layers of stone fruits 
Carotenoids are defined as colored compounds that consume free radicals and protect cell walls rom breakdown and oxidation. Furthermore, they prevent the formation of free oxygen radicals and increase the stability of the molecule. $\alpha$-carotene, $\beta$-carotene, and provitamin $A$ are among the most popular carotenoids [10]. $\beta$-carotene makes up more than $80 \%$ of the carotenoid content of apricot fruits [11]. The fruits also contain $\alpha$ carotene, $y$-carotene, zeaxanthin, and lutein [12].

[13] studied the chemical composition of a group of apricot cultivars grown in different regions of Turkey, and the carotene values ranged from 5.74 to $48.96 \mathrm{mg} / 100 \mathrm{~g}$ of dry weight in the studied apricot cultivars. In another study by [14], the content of carotenoids in three apricot cultivars grown in different regions of Croatia was studied, and the values ranged from 585.4 to $1374.95 \mathrm{mg} / 100 \mathrm{~g}$.

Carotenoids are a group of hydrophobic molecules with very low water solubility [15]. The process of extracting carotenoids is of high importance. Recent studies are moving towards extraction using safe and environmentallyfriendly solvents [16]. The commonly used solvents, such as petroleum, are considered dangerous and unsafe petroleum derivatives in the food industry [17]. The conventional solvents, such as n-Hexane, methanol, and tetrahydrofuran, require large quantities, a relatively long extraction time, and high temperatures. This causes the deterioration of large quantities of carotenoids during the extraction processes. Moreover, a small portion of the solvents may remain which is very dangerous due to their high toxicity [18]. The extraction conditions are the main determinant of the extraction yield, the most important of which are the type of solvent, the ratio of the solvent to the substance, the temperature, and the time of extraction (Wang \& Liu 2009) [19].

In a study by (Norshazila $S$ et al., 2017) [20] about determining the optimum conditions for extracting carotene from pumpkin, he concluded that using coconut oil at a temperature of $30^{\circ} \mathrm{C}$ for 12 hours is the optimum conditions for extracting carotenes.

\section{RESEARCH AIM}

Carotenoids are a group of hydrophobic molecules with very low water solubility [15]. The process of extracting carotenoids is of high importance. Recent studies are moving towards extraction using safe and environmentallyfriendly solvents [16]. The commonly used solvents, such as petroleum, are considered dangerous and unsafe petroleum derivatives in the food industry [17]. The conventional solvents, such as n-Hexane, methanol, and tetrahydrofuran, require large quantities, a relatively long extraction time, and high temperatures. This causes the deterioration of large quantities of carotenoids during the extraction processes. Moreover, a small portion of the solvents may remain which is very dangerous due to their high toxicity [18]. The extraction conditions are the main determinant of the extraction yield, the most important of which are the type of solvent, the ratio of the solvent to the substance, the temperature, and the time of extraction (Wang \& Liu 2009) [19] Given the scarcity of local studies on this field this research aims to study:

1) The effect of temperature $(20-40-60)^{\circ} \mathrm{C}$ and extraction time on the carotene extraction yield

2) The effect of the pretreatment (freezing refrigeration - fresh fruits) on the carotene extraction yield

3) Determining the optimum conditions for the extraction of carotenoids

4) The effect of the type of solvent (ethanol propanol) on the carotene extraction yield

\section{RESEARCH MATERIALS AND METHODS}

\subsection{Research Material}

Apricot fruits of the French cultivar were used at the degree of technical ripeness, which is characterized by large fruits and a yellowishorange color devoid of greenness. Moreover, the diameter of the fruits is not less than $3 \mathrm{~cm}$, and distinguished by their sweet taste and light sourness, as well as tolerance to processing, with greasy pulp and sweet non-sticky kernel, free from fungal infections and substances harmful to health. The average weight of one fruit is about $(28.48 \mathrm{~g})$, and the percentage of the edible portion of the pulp is about $(2 / 3) \%$.

The following solvents were used: ethanol - high purity propanol HPLC and the standards for both $\alpha$-carotene and $\beta$-carotene. 

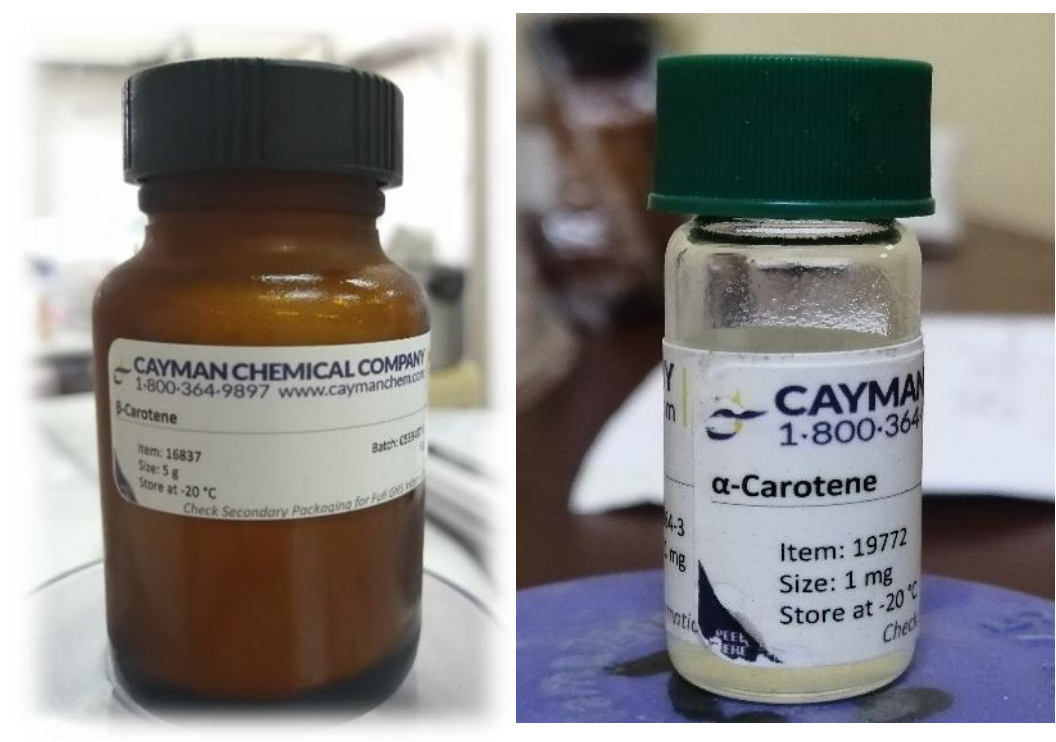

Fig. 2. Standards ( $\alpha$-carotene, $\beta$-carotene)

\subsection{Research Methods}

The work was carried out according to the following steps: First, ripe and healthy apricot fruits of the French cultivar were received from the local market and transported directly to the laboratory. Next, the fruits were sorted, washed, and dried. Finally, the analysis began.

Each of the following factors (type of solvent extraction time - temperature - pretreatment) were studied independently.

\subsection{Tests Conducted in the Research:}

\section{1- Estimation of Total Carotenoids}

Total carotenoids were determined using (Rangana., 1986) with minor modifications [21]. Five grams of apricot fruit pulp were crushed with acetone in a mortar. Next, the extract was taken to a cone where the process of crushing apricot fruits with acetone was continued until the remains became colorless. The collected extracts were transferred quantitatively to the separation conical and 25 to $30 \mathrm{ml}$ of petroleum ether with $5-10 \mathrm{ml}$ of $5 \%$ sodium sulfate were added. Petroleum ether was used repeatedly until all colors were transferred to the petroleum ether layer. The upper layer was transferred to a volumetric flask and the volume was completed to $50 \mathrm{ml}$ with petroleum ether. $30 \mathrm{ml}$ of it was taken to measure the absorbance at $452 \mathrm{~nm}$ using a spectrophotometer in order to determine total carotenoids. Then, the remaining $20 \mathrm{ml}$ was dried using a rotary evaporator and stored in the refrigerator until HPLC measurements were made. Each sample was reconstituted with $2 \mathrm{ml}$ of TBME (Tetra butyle methyl ether) and filtered using injection filters $(0.45 \mu \mathrm{m})$ for HPLC analysis. Total carotenoids were estimated using the following formula:

Total Carotenoids

$$
=\frac{3.85 * 0 . \mathrm{D} . * \text { Volume made } * 100}{\text { weight of sample } * 1000}
$$

\section{2- Estimation of $\beta$-carotene and $\alpha$-carotene}

$\beta$-carotene and $\alpha$-carotene were estimated according to the (Stoll et al., 2003: Liu et al., 2009) [22] method using a high-performance liquid chromatograph HPLC, (SHIMADZU-SPD$10 \mathrm{AV}$ ), and a (UV-VIS detector, the column used is of the type. The mobile phase: solvent A: (methanol/acetonitrile/double distilled water) $(84 / 14 / 2)(\mathrm{v} / \mathrm{v} / \mathrm{v})$ and solvent B (TBME): The mobile phase was prepared with a mixture of the two solvents $(80 \% \mathrm{~A})$ and $(20 \% \mathrm{~B})$. The mobile phase was prepared and then transferred to the ultrasonic degasser for degassing at laboratory temperature for 15 minutes. The flow rate was set at $1 \mathrm{ml} / \mathrm{min}$ at a wavelength of $450 \mathrm{~nm}$. By comparing the obtained peaks with the values of the standard standards prepared and preinjected into a series of concentrations (0.2-0.4$0.6-0.8-1) \mathrm{mg} / 100 \mathrm{ml}$ the retention time was calculated and $\beta$-carotene and $\alpha$-carotene concentration was determined and expressed as $\mu \mathrm{g} / 100 \mathrm{~g}$. 


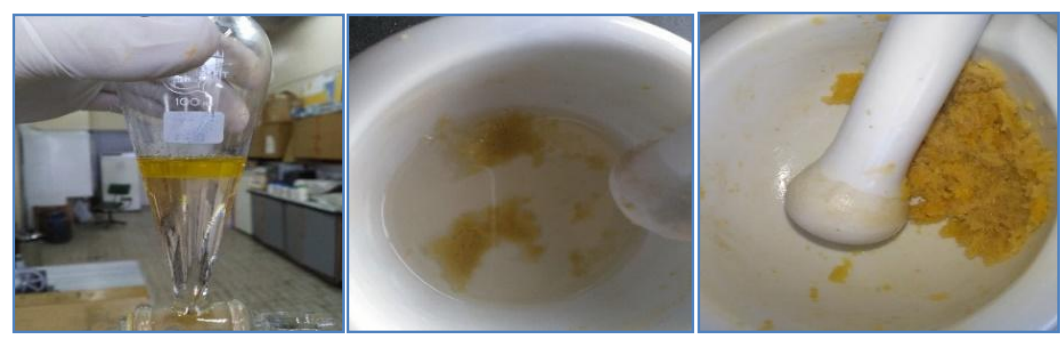

Fig. 3. The stages of carotenoids extraction

\section{3- Statistical Analysis}

The experiment was carried out according to a randomized complete block design with 3 replications. Analysis of variance ANOVA was conducted, and the averages were compared using the value of the least significant difference LSD at $5 \%$.

\section{RESULTS AND DISCUSSION}

\subsection{The Effect of Temperature on the Total Carotenoids Extraction Yield}

Table 1. Yield of carotene extraction at different temperatures $20-40-60^{\circ} \mathrm{C}$

\begin{tabular}{ll}
\hline $\begin{array}{l}\text { Extraction } \\
\text { Temperature }\left({ }^{\circ} \mathbf{C}\right)\end{array}$ & $\begin{array}{l}\text { Total carotenoids (B- } \\
\text { carotene) } \mathbf{~} \mathbf{~ g} / \mathbf{1 0 0 ~} \mathbf{~ g}\end{array}$ \\
\hline 20 & $2.24 \mathrm{C}$ \\
40 & $3.36 \mathrm{~b}$ \\
60 & $5.60 \mathrm{a}$ \\
\hline \multicolumn{2}{l}{ The different letters indicate the presence of significant } \\
differences at the level of significance $p<0.05$
\end{tabular}

From the data of Table (1) and Fig. (4), we note the effect of the extraction temperature on the yield of carotene at a fixed extraction time. At $20^{\circ} \mathrm{C}$, the extraction yield was very low and amounted to $2.24 \mathrm{mg} / 100 \mathrm{~g}$. When the extraction temperature was raised to $40^{\circ} \mathrm{C}$, an increase was observed. The extraction yield was significant and reached up to $3.36 \mathrm{mg} / 100 \mathrm{~g}$ of fresh fruits, i.e., an increase of the extraction yield by about 1.5 times. The extraction yield reached the highest value of $5.60 \mathrm{mg} / 100 \mathrm{~g}$ at a temperature of $60^{\circ} \mathrm{C}$, an increase of about 2.5 times compared to the extraction yield at a temperature of $20^{\circ} \mathrm{C}$.

From the foregoing we notice a significant and high increase in the extraction yield with the increase in the temperature at a fixed time of extraction. The temperature of $60^{\circ} \mathrm{C}$ is the optimum temperature for the extraction of carotene because the carotenoids are deposited inside the plant cells which are surrounded by membranes of a complex structure. Hence, increasing the temperature facilitates the breakdown of the cell wall which releases the carotenoids contained inside improving their extraction and increasing their solubility (Aflaki., 2012) [23]. This is inconsistent with the findings of (Oliveira et al., 2010) [24] that the carotenoids are destroyed at a temperature higher than $45^{\circ} \mathrm{C}$, and that the temperature of $30^{\circ} \mathrm{C}$ is the optimum temperature for the extraction of carotenoids.

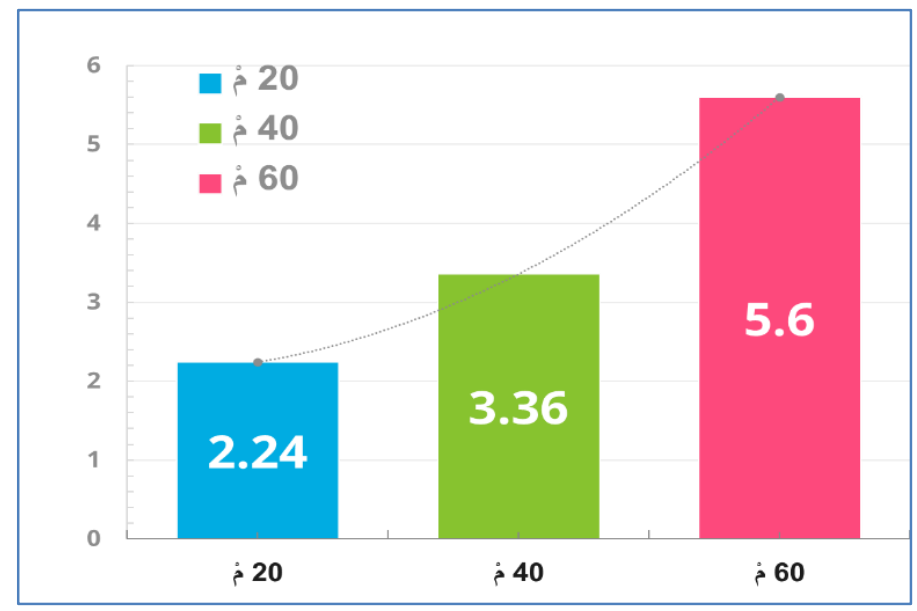

Fig. 4. Comparison of the effect of temperature on the yield of carotene extraction 


\subsection{The Effect of Extraction Time on the Total Carotenoids Yield}

Table 2. The effect of extraction time on total carotenoids yield

\begin{tabular}{ll}
\hline $\begin{array}{l}\text { Extraction time } \\
\text { (hour) }\end{array}$ & $\begin{array}{l}\text { Total carotenoids (B- } \\
\text { carotene) } \mathbf{~} \mathbf{~ g / 1 0 0 ~} \mathbf{~ g}\end{array}$ \\
\hline 4 & $2.24 \mathrm{a}$ \\
8 & $2.43 \mathrm{a}$ \\
12 & $2.52 \mathrm{a}$ \\
\hline \multicolumn{2}{r}{ The different letters indicate the presence of significant } \\
\multicolumn{2}{c}{ differences at the level of significance $p<0.05$}
\end{tabular}

From the table data there were no significant differences when increasing the extraction time at a constant temperature of $20^{\circ} \mathrm{C}$, which amounted to $2.24-2.43-2.52 \mathrm{mg} / 100 \mathrm{~g}$ when extracting for (4-8-12) hours in a row, and this slight increase in the extraction yield is due to the increase in the penetration of the solvent into the tissues of the plant cells, which leads to an increase in the rate of extraction. Nonetheless, increasing the time is not a sufficient factor for the release of carotenoids, so it is necessary to carry out some preliminary treatments to break down cell walls and release carotenoids or to increase the temperature to accelerate the release of carotenoids. This corresponds to the findings of (Strati and Oreopoulou., 2011)[25], i.e., the extraction yield increases with the increase in the extraction time in the first hours, and then decreases with increasing time until a state of equilibrium is achieved in the solvent after 45 minutes of extraction.

\subsection{The Effect of Pretreatment of Fruits, Temperature, and Time on the Total Carotenoids Extraction Yield}

From the data of Table (3) we note the effect of the pretreatment in refrigerated and freezing storage of apricot fruits on the yield of total carotenoids. The pretreatment by freezing was superior in increasing the yield of total carotenoids to all other treatments. This is due to the positive effect of freezing on breaking down cell walls of the plant cells of the apricot fruits which helps in the release of carotenoids bound inside the plant cell. The extraction rate increased from $2.10 \mathrm{mg} / 100 \mathrm{~g}$ to $2.52 \mathrm{mg} / 100 \mathrm{~g}$ after the first hour of extraction at a temperature of $40^{\circ} \mathrm{C}$. The extraction yield increased from 4.10 $\mathrm{mg} / 100 \mathrm{~g}$ in fresh fruits to $6.14 \mathrm{mg} / \mathrm{g} 100 \mathrm{~g}$ in frozen fruits after the first hour of extraction at a temperature of $60^{\circ} \mathrm{C}$, i.e., the pretreatment of fruits by freezing has led to an increase in the extraction yield by about $20 \%$ when extracting at a temperature of $40^{\circ} \mathrm{C}$, and about $50 \%$ when extracting at a temperature of $60^{\circ} \mathrm{C}$. This corresponds to what was referred to in (Dutta et al., 2005) [26] on the effect of the pretreatments, such as boiling and cooking, on releasing the protein-related carotenoids and making them easier to extract and estimate. It was also noted that the extraction yield increased significantly with the increase in the extraction time; the extraction rate increased from $3.90 \mathrm{mg} / 100 \mathrm{~g}$ to $6.45 \mathrm{mg} / 100 \mathrm{~g}$ at the fifth hour of extraction, i.e., the extraction rate increased by about $65 \%$.

Pigments and an increase in the extraction yield was observed starting from the first ten minutes when extracting at a temperature of $60^{\circ} \mathrm{C}$. No diffusion of pigments was observed during the extraction at $40^{\circ} \mathrm{C}$, and the extraction yield began to decrease at the fourth hour of extraction at a temperature of $60^{\circ} \mathrm{C}$ in all treatments: fresh fruits, refrigerated fruits, and frozen fruits. The optimum conditions for the extraction of carotenoids were: extraction at a temperature of $60^{\circ} \mathrm{C}$ for a period of three hours and treatment by freezing where the extraction rate reached $6.36 \mathrm{mg} / 100 \mathrm{~g}$.

Table 3. The effect of pretreatment, temperature, and time on the yield of carotenoid extraction

\begin{tabular}{|c|c|c|c|c|c|c|c|}
\hline \multirow{2}{*}{$\begin{array}{l}\text { Extraction } \\
\text { Time } \\
\text { (minute) }\end{array}$} & \multicolumn{3}{|c|}{ Extraction at $40^{\circ} \mathrm{C}$} & \multirow{2}{*}{$\begin{array}{l}\text { Extraction } \\
\text { Time } \\
\text { (minute) }\end{array}$} & \multicolumn{3}{|c|}{ Extraction at $60^{\circ} \mathrm{C}$} \\
\hline & Fresh & $\begin{array}{l}\text { Refrigerated } \\
\text { Storage }\end{array}$ & Frozen & & Fresh & $\begin{array}{l}\text { Refrigerated } \\
\text { Storage }\end{array}$ & Frozen \\
\hline 10 & -- & -- & -- & 10 & 2.59 & 2.92 & 3.72 \\
\hline 60 & 2.10 & 2.40 & 2.52 & 60 & 4.10 & 6.11 & 6.14 \\
\hline 120 & 2.13 & 2.52 & 2.57 & 120 & 4.22 & 6.27 & 6.25 \\
\hline 180 & 2.20 & 2.59 & 3.00 & 180 & 4.18 & 6.13 & 6.36 \\
\hline 240 & 2.37 & 3.14 & 3.60 & 240 & 3.98 & 6.00 & 6.45 \\
\hline 300 & 2.40 & 3.22 & 3.61 & 300 & 3.90 & 5.90 & 6.45 \\
\hline
\end{tabular}


From the above, and when comparing the effect of the pretreatment by refrigeration and freezing with fresh fruits, it was noted that the fruits treated with freezing were superior in increasing the extracted carotene yield, followed by the fruits treated by refrigeration, and this is due to the mechanical effect of the processes of refrigeration and freezing in breaking down cell walls and releasing carotenoids (Van Het Hof. et al., 2000) [27].

\subsection{The Effect of the Type of Solvent on the Total Carotenoids Yield}

From the data of Fig. (7) we note the difference in the total carotenoids yield according to the type of solvent used. The superiority of propanol in the carotene extraction yield is due to the difference in polarity. According to (Reichardt., 2003)[28] the polarity of ethanol is 0.645 , while the polarity of propanol is 0.546 , and carotenoids are non-polar compounds. This explains the superiority of propanol in increasing the total carotenoids yield. The degree of extraction is closely related to the natural properties of the solute that the solvent can dissolve according to its polarity (Warkoyo \& Saati 2011) [29]. Carotenoids also show different properties according to the type of carotenoids in the fruits; non-polar carotenoids such as $\beta$-carotene and lycopene are soluble in non-polar solvents, while polar carotenoids such as lutein are more soluble in polar solvents (Rivera \& Canela 2012)[30].

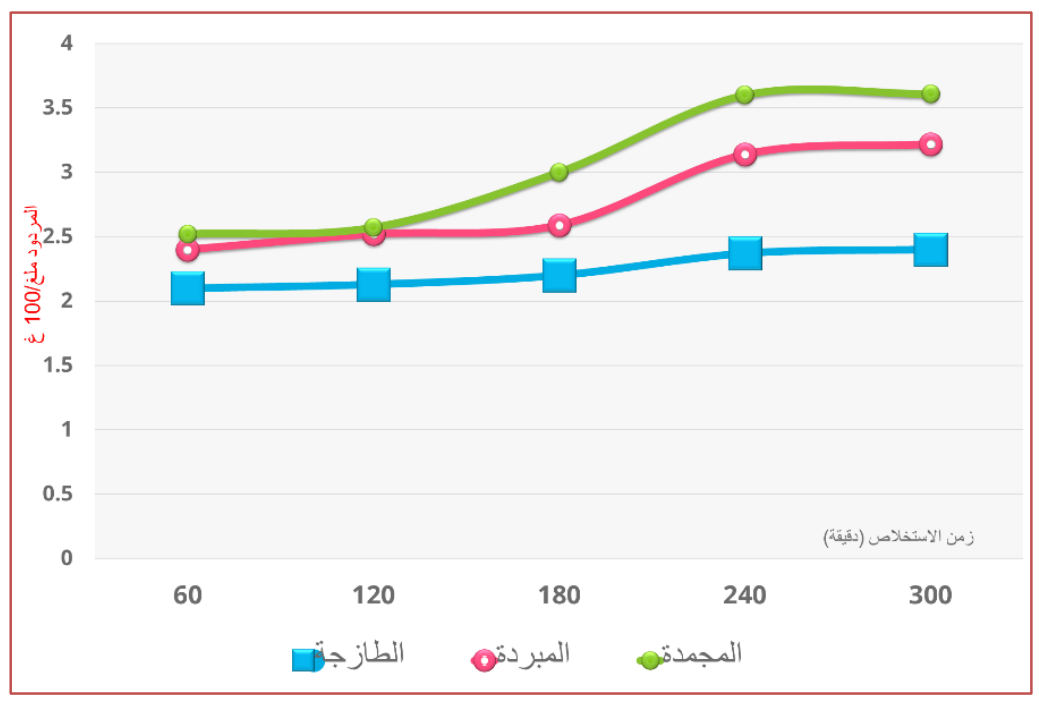

Fig. 5. The effect of the pretreatment on the effect of extracting carotene with ethanol at $40^{\circ} \mathrm{C}$

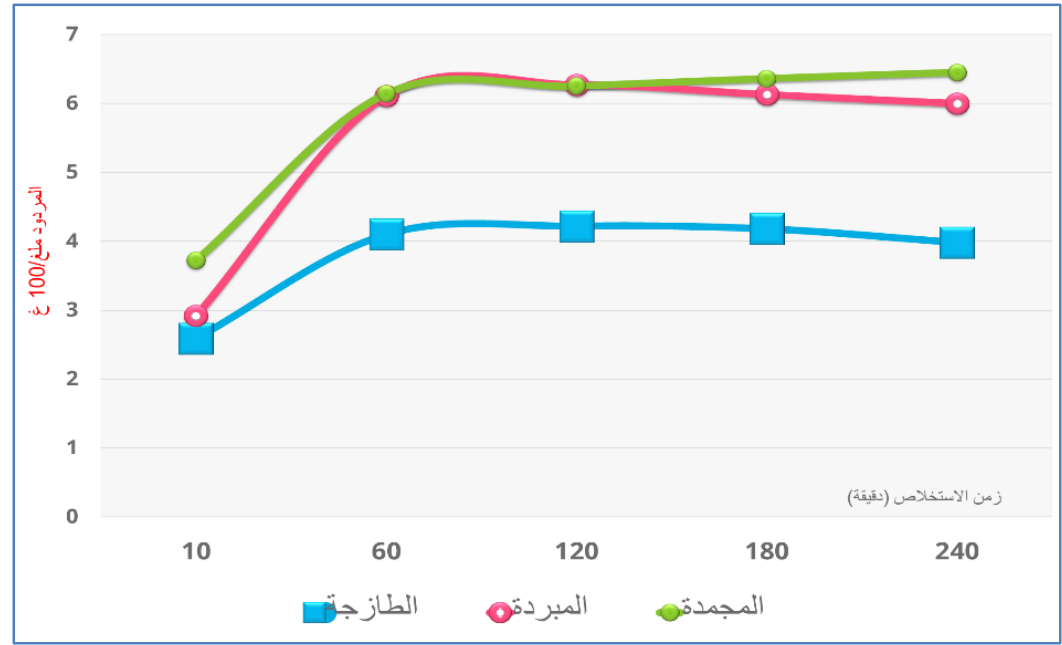

Fig. 6. The effect of the pretreatment on the effect of extracting carotene with ethanol at $60^{\circ} \mathrm{C}$ 


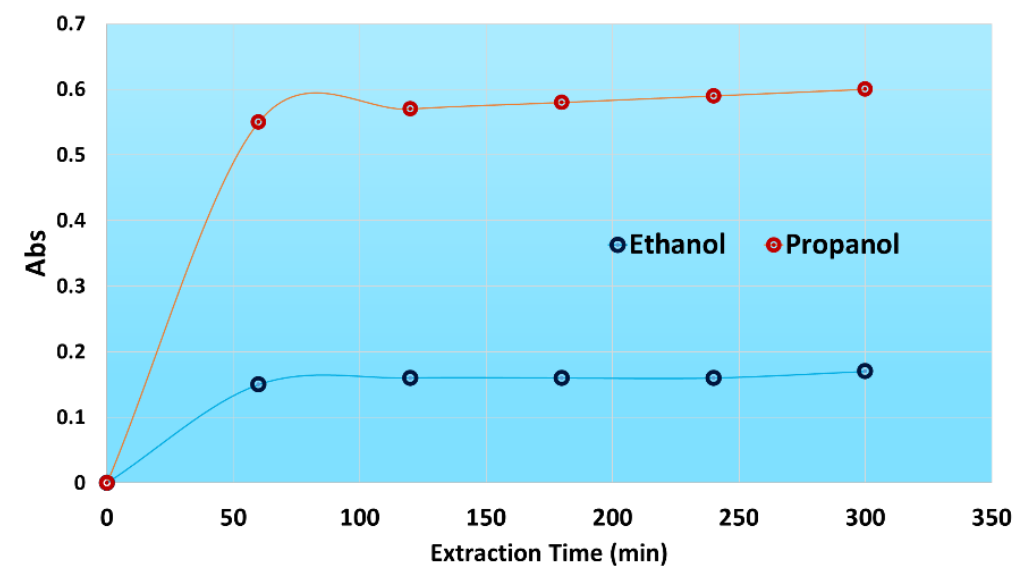

Fig. 7. Comparison of the solvent type in carotene extraction

Water-miscible, polar organic solvents, such as ethanol, are recommended for the extraction of carotenoids from the tissues that contain water and may be considered as a good extraction solvent for xanthophylls, but not for carotenoids. Hence, extraction by ethanol provided the lowest carotene yield compared to other solvents. However, the most suitable solvents used to extract carotenoids from pumpkin were ethyl acetate and virgin coconut oil; they have given a high yield of carotenoids. Hence, virgin coconut oil was chosen as a solvent for further optimum study as it is natural and safe for consumption.

\section{CONCLUSIONS}

We conclude from the above:

1) Propanol is the most suitable solvent for carotenoids extraction in comparison to ethanol.

2) Extraction yield is very low at $20^{\circ} \mathrm{C}$.

3) Significant increase in extraction yield with time in the first hours of extraction, and there was no significant effect of increasing extraction time at 6-8 hours.

4) Significant increase in the extraction yield with an increase in temperature at a fixed time of extraction, and the temperature of $60^{\circ} \mathrm{C}$ is the optimum temperature for the extraction of carotene.

5) The optimum conditions for the extraction of carotenoids are: extraction at the temperature of $60^{\circ} \mathrm{C}$ for three hours with a pretreatment by freezing where the extraction rate reached $6.36 \mathrm{mg} / 100 \mathrm{~g}$.

\section{SUGGESTIONS}

From the above we recommend:
1) Using of ethanol as a water-miscible organic food solvent because it is a safe solvent.

2) Continuation of the study by using other solvents of different polarity in extracting carotenoids and studying the extraction yield.

3) Modifying the extraction method by adjusting the used temperatures and modifying the extraction stages.

\section{DISCLAIMER}

The products used for this research are commonly and predominantly use products in our area of research and country. There is absolutely no conflict of interest between the authors and producers of the products because we do not intend to use these products as an avenue for any litigation but for the advancement of knowledge. Also, the research was not funded by the producing company rather it was funded by personal efforts of the authors.

\section{COMPETING INTERESTS}

Authors have declared that no competing interests exist.

\section{REFERENCES}

1. Al-Hamid Adnan. Packaging and storage of fruits, Aleppo University Publications. $2001 ; 282$.

2. Al-Saed Ali Kamel. Canning and cooling fruits and vegetables, College of Agriculture - University of Jordan, Food Processing Series. 2009;5-6. 
3. Srivastava RP, Sanjeev Kumar. Fruit and vegetable preservation, principles and practices. Third edn. Army printing press Lucknow. India. 2002;11-20.

4. Statistical Group of the Ministry of Agriculture and Agrarian Reform, Syrian Arab Republic; 2012.

5. Andrzej L. Osmotic dehydration of fruits and vegetables; 2014.

6. Egea IM, Martinez-Madrid MC, SanchezBel P, Murcia MA, Romojaro F. The inflence of electron-beam ionization on ethylene metabolism and quality parameters in apricot (Prunus armeniaca L., cv Búlida). LWT-Food Science and Technology. 2007;40:1027-1035.

7. Jimenez AM, Martınez-Tome M, Egea I, Romojaro F, Murcia MA. Effect of industrial processing and storage on antioxidant activity of apricot (Prunus armeniaca v. bulida). European Food Research and Technology. 2008;227:125-134.

8. Murcia MA, Jimenez AM, Martinez-Tome $M$. Evaluation of the antioxidant properties of Mediterraneanand tropical fruits compared with common food additives. Journal of Food Protection. 2001;64:20372046.

9. Swenson Oufnac D. Determination of antioxidant capacity in corn germ, wheat germ and wheat bran using solvent and microwave-assisted solvent extraction; B.S. Culinary Arts, Nicholls State University, 1999, Submitted to the Graduate Faculty of the Louisiana State University and Agricultural and Mechanical College in partial fulfillment of the requirements for the degree of Master of Science, The Department of Food Science; 2006.

10. Anna Podsedek. Natural antioxidants and antioxidant capacity of Brassica vegetables: A review, LWT. 2007;40: $1-11$.

11. Sağırlı F, Tagı S, Dzkan M, Yemis D. Chemical and microbial stability of high moisture dried apricots during storage.Journal of the Science of Food and Agriculture. 2008;88(5):858-869.

12. Fraser PD, Bramley PM. The biosynthesis and nutritional uses of carotenoids. Progress in Lipid Research. 2004;43(3):228-265.

13. Akin EB, Karabulut I, Topcu A. Some compositional properties of main Malatya apricot (Prunus armeniaca L.) varieties. Food Chemistry. 2008;107:939-948.
14. Karabulut I, Topcu A, Duran A, Turan S, Dzturk B. Effect of hot air drying and sun drying on color values and $b$-carotene content of apricot (Prunus armenica L.). Lebensmittel-Wissenschaf undTechnologie. 2007;40(5):753-758.

15. Jomova K, Valko M. Health protective effects of carotenoids and their interactions with other biological antioxidants. European Journal of Medicinal Chemistry. 2013;70:102-110.

16. Fikselova M, Silhar S, Marecek J, Francakova H. Extraction of carrot (Daucus carota L.) carotenes under different conditions. Czech Journal of Food Sciences. 2008;26:268-274.

17. Ishida BK, Chapman MH. Carotenoid extraction from plants using a novel, environmentally friendly solvent. Journal of Agricultural and Food Chemistry. 2009;57:1051-1059.

18. Durante M, Lenucci MS, Mita G. Supercritical carbon dioxide extraction of carotenoids from pumpkin (Cucurbita spp.): A review. International Journal of Molecular Sciences. 2014 ;15:6725-6740.

19. Wang, L. \& Liu, Y. 2009. Optimization of solvent extraction conditions for total carotenoids in rapeseed using response surface methodology. Natural Science 1: 23-29.

20. Norshazila S, Irwandi J, Othman R, Yumi Zuhanis $\mathrm{HH}$. Carotenoid content in different locality of pumpkin (Cucurbita moschata) in Malaysia. International Journal of Pharmacy and Pharmaceutical Sciences. 2014;6:29-32.

21. Rangana S. Handbook of analysis and quality control for fruit and vegetable products, McGraw-Hill Puplishing Company; 1999.

22. Stoll T, Schweiggert U, Schieber A, Carle $\mathrm{R}$, Application of hydrolyzed carrot pomace as functional food ingredient to beverages. J Food Agric Environ. 2003: 1:88-92

23. Aflaki, N. 2012. Optimization of carotenoid extraction in peel and flesh of cantaloupe (Cucumis melo L.), with ethanol solvent. MSc. thesis. Laval University, Canada.

24. Oliveira RGA, Carvalho MJL, Nutti RM, Carvalho LVJ, Fukuda WG. Assessment and degradation study of total carotenoid and B-carotene in bitter yellow cassava (Manihot esculenta crantz) varieties. African Journal of Food Science. 2010;4: 148-155. 
25. Strati IF, Oreopoulou V. Effect of extraction parameters on the carotenoid recovery from tomato waste. International Journal of Food Science and Technology. 2011;46: 23-29.

26. Dutta D, Raychaudhuri U, Chakraborty R. Retention of $\beta$-carotene in frozen carrots under varyingconditions of temperature and time of storage. African Journal of Biotechnology. 2005;4:102- 108.

27. Van Het Hof $\mathrm{KH}$, West CE, Westrate JA, Hautvast JA. Dietary factors that affect the bioavailability of carotenoids. Journal of Nutrition. 2000;130:503-506.

28. Reichardt C. Solvents and Solvent Effects in Organic Chemistry. Germany: WileyVCH Publishers; 2003.

29. Warkoyo, Saati EA. The solvent effectiveness on extraction process of seaweed pigment. Makara, Teknologi. 2011;15:5-8.

30. Rivera S, Canela R. Influence of sample processing on the analysis of carotenoid in maize. Molecules 2012;17:11255-11268.

(C) 2021 Kalook et al.; This is an Open Access article distributed under the terms of the Creative Commons Attribution License (http://creativecommons.org/licenses/by/4.0), which permits unrestricted use, distribution, and reproduction in any medium, provided the original work is properly cited.

Peer-review history:

The peer review history for this paper can be accessed here: https://www.sdiarticle4.com/review-history/72933 